\title{
低レイノルズ数の片複断面開水路流れに 形成される斜昇流の内部構造
}

\author{
渡辺＼cjkstart勝利 1 ・森山 拓士2・佐賀 孝徳3 \\ 1正会員＼cjkstart徳山工業高等専門学校土木建築工学科（７745-8585 山口県周南市学園台） \\ E-mail: watanabe@tokuyama.ac.jp \\ 2正会員 中電技術コンサルタント株式会社（†734-8510 広島市南区出汐2丁目3番30号） \\ 3正会員＼cjkstart徳山工業高等専門学校土木建築工学科（干745-8585 山口県周南市学園台）
}

\begin{abstract}
低レイノルズ数の片複断面開水路流れにおける斜昇流の内部構造の特徵を，流速計測法と可視化法を用 いて考察した。斜昇流の形成が卓越する高水敷水深が比較的大きい流れでは, 縦渦構造が集中して形成さ れる領域が高水敷上に複数存在する。 とくに高水敷先端部には，水表面まで発達する縦渦構造が安定して 形成されることが認められた。この構造は低水路方向への傾斜運動が顕著であり，時針，反時針方向の旋 回状の瞬時二次流れ，局所的な低速領域，瞬時レイノルズ応力の生成に直接寄与している.このような瞬 時の速度場の形成に寄与する縦渦構造の高水敷先端部における時空間的集中によって, 長時間平均特性で ある斜昇流を内包した対を成す大規模な旋回状の二次流分布が生成されることが明らかとなった.
\end{abstract}

Key Words : compound open channel flow, oblique upward flow, streamwise vortex, secondary flow, flow visualization

\section{1. 緒 論}

複断面開水路流れは，低水路内と高水敷上の速度差の

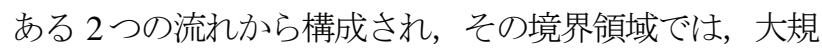
模なせん断層の形成に伴い，運動量や物質の輸送現象が 顕著になることが知られている.これまでに，この流れ 場に関する数多くの研究が行われ，大規模水平渦，斜昇 流という複断面開水路流れ固有の組織構造の存在が明ら かにされている.

水平渦は，鉛直方向に軸を持つ大規模な渦構造であり， Sellin ${ }^{1}$ にってその存在が初めて示された. その後, 水 平渦に関する詳細な検討が進められ，三次元構造 ${ }^{2)}$ や形 成条件 ${ }^{3)}$, 形成機構 ${ }^{4}$ に関する究明がなされている.

一方，斜昇流は，高水敷先端近傍から低水路側の自由 表面に向から顕著な二次流れであり，今本，久下 5よ って見出された．彼らは，熱線流速計を用いて片複断面 開水路流れの流速計測を行い，高水敷の先端には斜昇流 に伴って水表面方向へ舌状に広がる低速域が存在し，そ こでは乱れ強度，レイノルズ応力が極めて大きくなるこ とを明らかにした。

このような重要な特性を有する斜昇流について, さら に詳細な究明が実験および数值計算によって進められて いる.
Tamai $5^{6}$ ) は，水素気泡法を用いて流れの内部構造を 観察し，高水敷先端部に縦渦構造が形成されることを見 出し，それが斜昇流や水平渦の生成に密接に関係してい ることを指摘した. Tominaga \& Nezu`は，FLDA を用い て複断面開水路流れの流速計測を行い，平均流速や乱れ の詳細な分布を示すとともに，それらの分布が流れ場に 形成される二次流れに強い影響を受けること，また，斜 昇流は，高水敷と低水路の境界部に生成される高水敷渦 と低水路渦という一対の縦渦に起因していることを示唆 した. 襧津, 鬼束ら ${ }^{8)}$ は, かぶり水深の変化に伴う複断 面開水路流れの特徴を LDA および PIV を用いて詳細に 検討した. その結果, 流れ場の特性は低水路水深と高水 敷高さの比に依存しており，斜昇流はその值(低水路水 深/高水敷高さ)が 1.5 よりも大きい流れ場において卓越 することが示された。 また，その流れ場では，高水敷と 低水路の境界付近に発生する水平方向に軸を持つ渦と水 平渦が斜昇流の生成に寄与していることが明らかにされ た.さらに, 禰津, 山上ら ${ }^{9}$ は, 非定常の複断面流れの 内部構造についても検討し, 水位, 流量の変化よって斜 昇流の特徴が異なることを示した。石垣，今本 ${ }^{10)}$ は，可 視化法を用いて片複断面開水路流れの内部構造を検討し た. 可視化法には水素気泡法，中立粒子トレーサ法が用 いられ，本流れ場には，低水路流れと高水敷流れの速度 
差に起因する渦構造と斜昇流が存在しており, 斜昇流が 縦渦を生成することが示唆された. Shiono \& Feng ${ }^{11)}$ は, 直線開水路と複断面開水路の流れ場に注入された染料の 濃度分布を計測し，その分布特性と流れ場に形成される 二次流れの構造との相互関係を考察した，その結果，複 断面開水路流れでは，斜昇流を含めた顕著な二次流れが， 濃度分布の最大值や濃度の輸送率に支配的な役割を果た していることが明らかにされた。

斜昇流に関する数值計算による究明も進められている. 佐藤ら ${ }^{12)}$ は LES (Large Eddy Simulation)を用いて片複断面 開水路流れの数值計算を行い，斜昇流とそれが作る高水 敷上の渦を良好に再現するとともに，斜昇流はレイノル ズ応力のせん断成分そのものに起因することを明らかに した．杉山，秋山ら ${ }^{13} /$ ，代数レイノルズ応力モデルを 用いて数值解析を行い，斜昇流等の実験結果を良好に再 現するとともに，斜昇流の生成機構を渦度輸送方程式を 用いて定量的に考察した．また，杉山，亀澤ら ${ }^{14}$ は，傾 斜側壁を有する複断面開水路流れについて，同モデルを 用いて高水敷先端部における縦渦の発達挙動を明らかに した. Naot ${ }^{15}$ は，準等方性代数応力モデルを用いて数 值計算を行い, 高水敷先端部の縦渦対を良好に再現し, 高水敷高さの減少に伴って縦渦対の強度が対称になるこ とを予測した．Jong \& Choi ${ }^{16}$ は，DNS(Direct Numerical Simulation)を複断面開水路流れに適用寸ることにより， 高水敷先端部に対を成す渦構造が存在し, それが高水敷 側および低水路側の二次流れの生成に寄与していること を明らかにした。

以上のような複断面開水路流れに関する既往の研究に より，斜昇流に関する平均流特性，乱れ特性，さらには その形成機構に関する重要な知見が得られた. 斜昇流の 形成においては, 水平渦や縦渦構造との相互関係が指摘 されているが，それらの実体や時空間的な特性について は十分な解明には至っていない上うに思われる。また， 斜昇流は第二種二次流と位置付けられ，その形成に果た 寸渦構造の役割の解明は重要な課題と考えられる.

著者らは，斜昇流と同様に顕著な二次流れを伴う並列 らせん流の内部構造を検討した ${ }^{17}$. その際には, 並列ら せん流を安定して形成させるために，開水路の底壁面上 に台形断面の栈型粗度を水深の二倍の間隔で流れ方向に 設置し, 流速分布, 組織構造の時空間特性を明らかにす るとともに, 組織構造と瞬時速度分布との相互関係を詳 察した，その結果，並列らせん流の特徵である水表面流 速における水深の 2 倍程度の遅速分布および水深規模の 旋回流は, 栈粗度上に形成された大規模な縦渦構造の時 空間的な集中によって生成され，その集中領域は，主流 速の鈶直方向のせん断 ( $\partial U / \partial y)$ と横断方向のせん断 $(\partial U / \partial z)$ の 2 つの速度せん断の共存する領域に対応して

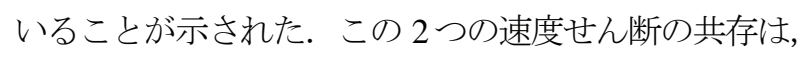

複断面開水路流れの高水敷と低水路の境界付近にも認め られることから, 斜昇流の形成においても縦渦構造の寄 与が推察される. 著者らは, 流れの可視化法を用いて, 滑面直線開水路流れに形成された縦洞構造の諸特性に関 しても究明を進め $\left.\left.{ }^{18)}, 19\right), 20\right)$, 縦渦構造が瞬時の二次流孔 やレイノルズ応力の生成に直接寄与していることを明ら かにした. また, 水表面に到達する大規模な縦渦構造を 対象に, その流れ方向, 横方向スケールを明らかにし, それらが壁面の粗滑，レイノルズ数に依らずほぼ同一で あることを示唆した ${ }^{17}$.このように縦渦構造は乱流場の 形成において極めて重要な普遍的構造であり, その解明 は流れの本質を理解するために不可欠と考えられる.

以上のことを踏まえて, 本研究では, 斜昇流の内部構 造の特徴を明らかにすることを目的として，片側岸に高 水敷を有する片複断面開水路流れにおける縦渦構造の諸 特性を流速計測法，流れの可視化法を用いて詳細に検討 した. その結果, 斜昇流の形成に関わる縦渦構造の存在 とその時空間特性, 速度情報との相互関係が明らかとな り, これらの知見を踏まえて, 斜昇流の内部構造に関す

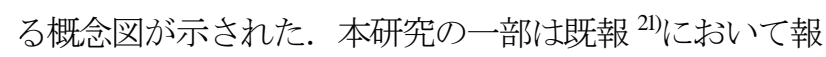
告されているが, その後, 新たなデー夕, 考察を付け加 えて再構成した.

\section{2. 実験装置および方法}

実験には，図-1 に示した長さ $10 \mathrm{~m}$, 幅 60cm, 高さ $15 \mathrm{~cm}$ の透明アクリル樹脂板製の滑面直線開水路を使用 した。本水路の右岸側の底壁面上に, 長さ $1 \mathrm{~m}$, 幅 $\left(B_{\tilde{f}}\right) 15 \mathrm{~cm}$, 高さ $(D) 4 \mathrm{~cm}$ の塩ビ樹脂板を上流から $8 \mathrm{~m} の$ 区間に設置した. 水路上流端には整流装置として八ニカ 么 (径 $4 \mathrm{~mm}$, 長さ $3.2 \mathrm{~cm}$, 幅 $60 \mathrm{~cm}$ ), 下流端には水路調 整用の堰を設置した. 水路勾配は $1 / 1000$ に設定した,

本水路の上流から $5 \mathrm{~m}$ 付近の地点において, 流速計測 および内部流況の可視化を行った。流速計測には PTV(Particle Tracking Velocimetry)を採用した. トレーサー には平均粒径 $150 \mu \mathrm{m}$ ，比重 1.04 の微細粒子を，照明には スライドプロジェクター $(1 \mathrm{KW})$ の厚さ $2 \mathrm{~mm}$ スリット光 膜を用いた. この微細粒子と水との混相液を, 上流端か ら流れに連続的に注入した後, 流れの三断面(維断, 水 平, 横断)におけるトレーサー粒子の流動状況をデジタ ルビデオカメラ(SONY DVX-2000)で撮影した. 図-2(a)は 水平断面視の概略, 図-3 には PTV の計測断面位置を示 した. なお，横断面内の瞬時の二次流を計測する際には， 微細粒子の移動が追跡可能となるように，スリット光膜 の厚さを調整し，後述のように下流に設置した鏡を通し て粒子の流動状況を撮影した. PTVの解析においては, 可視化画像 $(640 \times 480$ ピクセル)を連続的にコンピュータ 


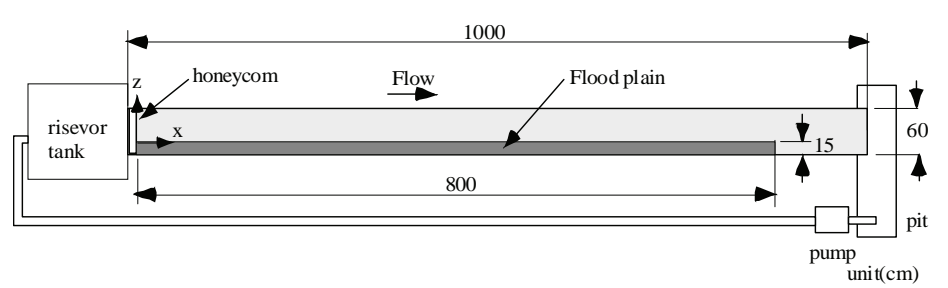

図-1 実験水路概略 (平面図) および座標系

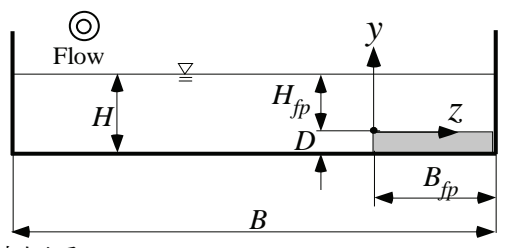

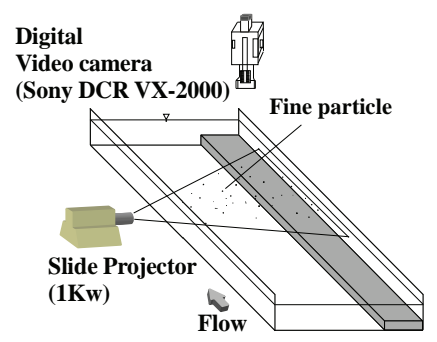

(a) 水平断面視

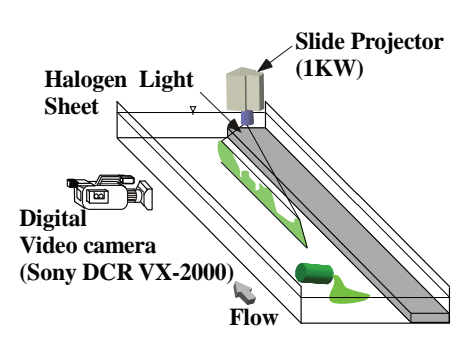

(b) 縦断面視

図-2 流速計測法および流れの可視化法概略

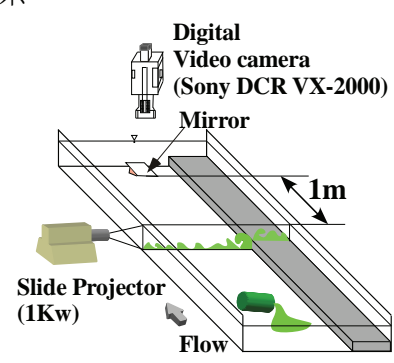

(c) 横断面視

表-1 実験条件

\begin{tabular}{|c|c|c|c|c|c|c|c|}
\hline Case & \begin{tabular}{|c|}
$\begin{array}{c}H \\
(\mathbf{c m})\end{array}$ \\
\end{tabular} & $\begin{array}{c}D \\
(\mathrm{~cm}\end{array}$ & $\begin{array}{l}H_{f p} \\
(\mathbf{c m})\end{array}$ & $H / D$ & $\begin{array}{c}U_{m} \\
(\mathrm{~cm} / \mathrm{s})\end{array}$ & $\begin{array}{c}R e \\
(U m H / v) \\
\end{array}$ & $\begin{array}{c}F r \\
\left(\mathrm{Um} /(\mathbf{g H})^{0.5}\right.\end{array}$ \\
\hline $\mathbf{A}$ & \begin{tabular}{|l|}
8.0 \\
\end{tabular} & \multirow{7}{*}{4.0} & 4.0 & 2.0 & 5.7 & 5202 & 0.064 \\
\hline B & 8.0 & & 4.0 & 2.0 & 7 & 391 & 053 \\
\hline C & \begin{tabular}{|l|}
8.0 \\
\end{tabular} & & 4.0 & 2.0 & 3 & 2979 & 0.037 \\
\hline D & 6.0 & & 2.0 & 1.5 & 4.8 & 3323 & 0.062 \\
\hline $\mathbf{E}$ & 5.0 & & 1.0 & 1.3 & 4.3 & 2490 & 0.061 \\
\hline$\overline{\mathbf{F}}$ & \begin{tabular}{|l|}
3.7 \\
\end{tabular} & & 0.0 & 0.9 & 6.5 & 2806 & 0.108 \\
\hline G & 12.0 & & 8.0 & 3.0 & 3.4 & 4690 & 0.031 \\
\hline
\end{tabular}

に取り込んだ後，2 值画像相関法を採用した流体計測ソ フトウエア「Flow PTV」（(株)ライブラリ)を用いて瞬時 流速成分を算出し，それらの統計処理を行い平均流速分 布等を求めた. 取り込み時間（画像数）は 1 秒当たり 30 枚として 60 秒間 (1800 枚)，壁面近傍の流速計測にお いては120秒間(3600枚)とした。

組織構造の可視化では, トレーサーに蛍光染料(フル オレセインナトリウム) 水溶液（比重 1.005），照明には 前出のスリット光膜を用いて流れの縦断面視 (図-2(b)) , 横断面視(図-2(c))を行った。断面視では，本トレーサー を可視化断面位置の約 $2 \mathrm{~m}$ 上流から一定量（約 200cc） を注入した後, 注入に伴う初期の撹乱部分が流下した後, 可視化断面における流況を同ビデオカメラで撮影した. 横断面視では可視化断面から $1 \mathrm{~m}$ 下流の位置に設置した 鏡 $(5 \times 5 \mathrm{~cm})$ を用いて撮影した。この鏡の設置位置は， 注入した染料水溶液の流動状況を観察し，鏡の影響が可 視化断面に及ばないことを確認して決められた。また， 組織構造と速度情報を同時注出するために DPTV（Dyestreak-pattem Particle Tracking Velocimetry) ${ }^{18)}$ を流れの縦断面, 水平断面, 横断面に適用した。本手法では, 前出の微細 粒子と蛍光染料水溶液を同時に流れに注入し，スリット 光膜内に可視化されるトレーサーの流脈形象と粒子流動 画像を前出の同ビデオカメラで撮影した. なお, DPTV を横断面視へ適用する際には，横断面 PTV と同様に， スリット光膜の厚さを調整した.

実験条件の詳細は表-1 に示すとおりである. 本実験
では，既往の研究成果を参考に，斜昇流が卓越する低水 路水深 $(H)$ と高水敷高さの比 $(H / D)$ が 1.5 以上の条件を中 心に選択した。 また, 組織構造の明瞭な可視化画像を得 るために低レイノルズ数の条件を設定した。

\section{3. 実験結果および考察}

\section{（1）平均流速分布特性}

図-4 には, Case $\mathrm{A}(H=8 \mathrm{~cm})$ における平均主流速分布 $(U)$, 二次流分布 $(V, W)$, レイノルズ応力分布 $(-\overline{U w},-\overline{-i v})$ を示している. 二次流成分 $V, W$ には，縦断面 PTV，水 平断面 PTV からそれぞれ得られた長時間平均量を使用 した. (a)の平均主流速分布においては，高水敷の低水路 側端部(以下，高水敷先端部と呼ぶ) 周辺において，主流 速の等值線が水表面に向かって, 対岸方向に斜めに張り 出していることが明らかである。この特徵は，(b)に示 した二次流ベクトルとの重合図から，同領域に形成され た強い斜昇流の影響によることが明瞭である。この斜昇 流は時針, 反時針方向の対を成す大規模な旋回状の二次 流分布（以下，旋回流と呼ぶ）の上昇部に相当している. (c), (d)は, 高水敷近傍の主流速の鉛直方向分布 $(U(y))$, 横断方向分布 $(U(\mathrm{z}))$ をそれぞれ示している. これらより, 高水敷先端部 $(y=0, z=0)$ 付近では，局所的な低速部を挟 む 2 つの速度せん断( $\partial U / \partial y, \partial U / \partial z)$ の生成が認められる。 また，壁面付近の主流速横断方向分布においては，高水 


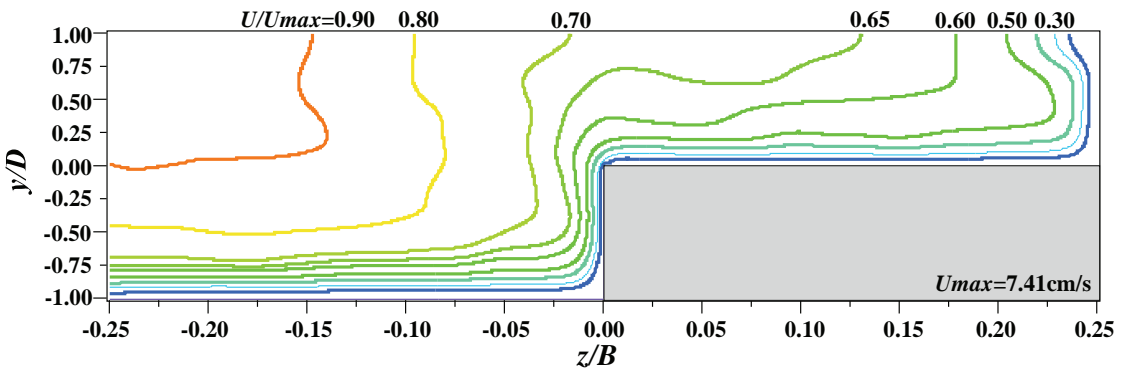

(a)主流速 $(U)$ 等值線図

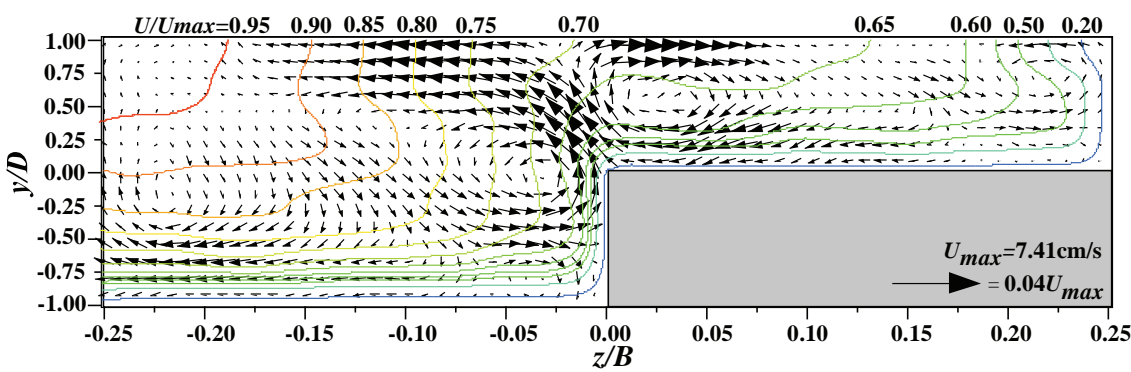

(b)二次流分布 $(V, W)$

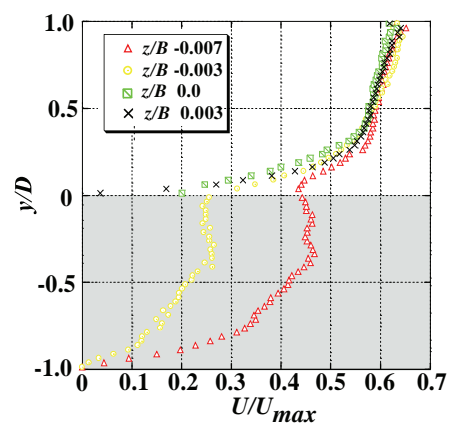

(c)主流速鉛直方向分布 $U(y)$

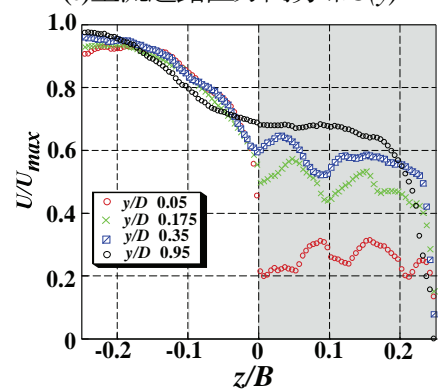

(d)主流速横断方向分布 $U(z)$

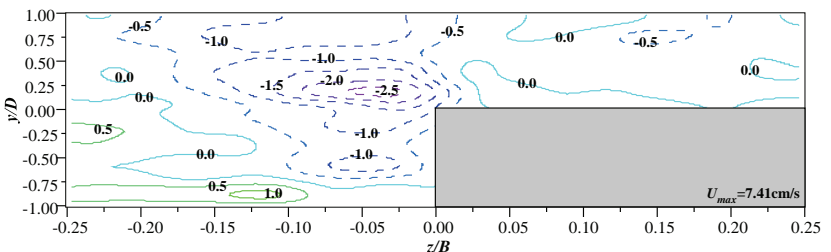

(e)水平方向レイノルズ応力分布 $\left(-\overline{u w} / U_{\max }{ }^{2}\right) \times 10^{3}$

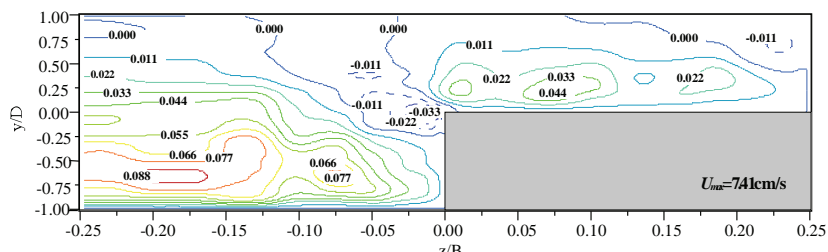

$(\mathrm{f})$ 鉛直方向レイノルズ応力分布 $\left(-\overline{u v} / U_{\operatorname{mox}}{ }^{2}\right) \times 10$

図-4 平均流速分布 (Case A)

敷先端部以外にも $z / B=0.1,0.2$ 付近に局所的な低速領域 の形成が認められる．同図(e), (f)には，水平および鉛直 方向レイノルズ応力 $(-\overline{u N},-\overline{-n})$ の等值分布をそれぞれ示 している，- - - 分布においては，負值が高水敷先端部の 低水路側に横長の楕円状に分布し，その最大值は高水敷 先端部付近に位置している. またその分布領域は, 図一 4(b)の二次流分布における反時針方向の旋回流の形成領 域に対応している，一方，- $-\bar{N}$ 分布では，壁面付近に最 大值が生ずる通常のレイノルズ応力分布が高水敷および 低水路上に生成されている. また，高水敷先端部から水 表面方向に，負值の領域が斜めに分布していることが明 らかである.この分布領域は斜昇流に沿っており，最大 值は--uw分布と同様に, 高水敷先端部の低水路側で生じ ている. 以上の本流れ場の流速分布特性は, 高レイノ ルズ数で行われた既往の実験結果 7,8) とほぼ同様である ことが認められた。

\section{（2） 瞬時二次流分布}

高水敷先端部には, 時間平均特性として図-4(b)に示し たように，斜昇流を内包した対を成す大規模な旋回流が 形成されている. これらの形成過程を理解するために, 瞬時に生成される二次流れの分布特性を考察した. 複断
面開水路流れにおける瞬時二次流れの特徵については, 数值計算による研究結果 ${ }^{12,14,116}$ に認められるものの, 実 験的に捉えた例は石垣，今本 ${ }^{10)}$ の研究のみである. 本研 究では流れの横断面に PTV を適用することにより, 瞬 時の二次流分布の経時変化を捉えることができた.

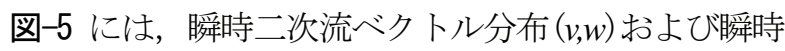
渦度分布 $\omega_{x}(=\partial w / \partial y-\partial v / \partial z)$ の $1 / 3$ 秒毎の経時変化を示して いる.これらより, 瞬時の二次流分布について, 次の 3 つの特徽が指摘される. その 1 つ, 高水敷先端部周辺 には，時針および反時針方向の旋回流が，単独あるいは 対の形態で集中して形成されることである. $T=0.0 \mathrm{sec} に$ おける反時針方向の旋回流 A は $T=2.0 \mathrm{sec}$ まで低水路側 に存在し，その形成領域は比較的高い渦度領域に相当し， 経過時間に伴って縮小している. B，C は時針方向の旋 回流であり， $T=2 / 3 \mathrm{sec}$ ではそれぞれ単独で存在している が， $T=1.0 \mathrm{sec}$ 以降では複合して旋回流 A と対を成寸形態 を呈し，T=3.5sec 以降で消失している. 旋回流 A， B，C が消失した後, $T=7 / 3 \mathrm{sec}, 8 / 3 \mathrm{sec}$ では時針方向の旋回流 D, 反時針方向の旋回流が出現し, 対を成寸形態で存在して いることが認められる. 2 つめ特徵は, 高水敷先端部 の斜昇流は上述の旋回流の上昇部に相当していることで ある. 図中には, 高水敷先端部の斜昇流の方向を白抜き 

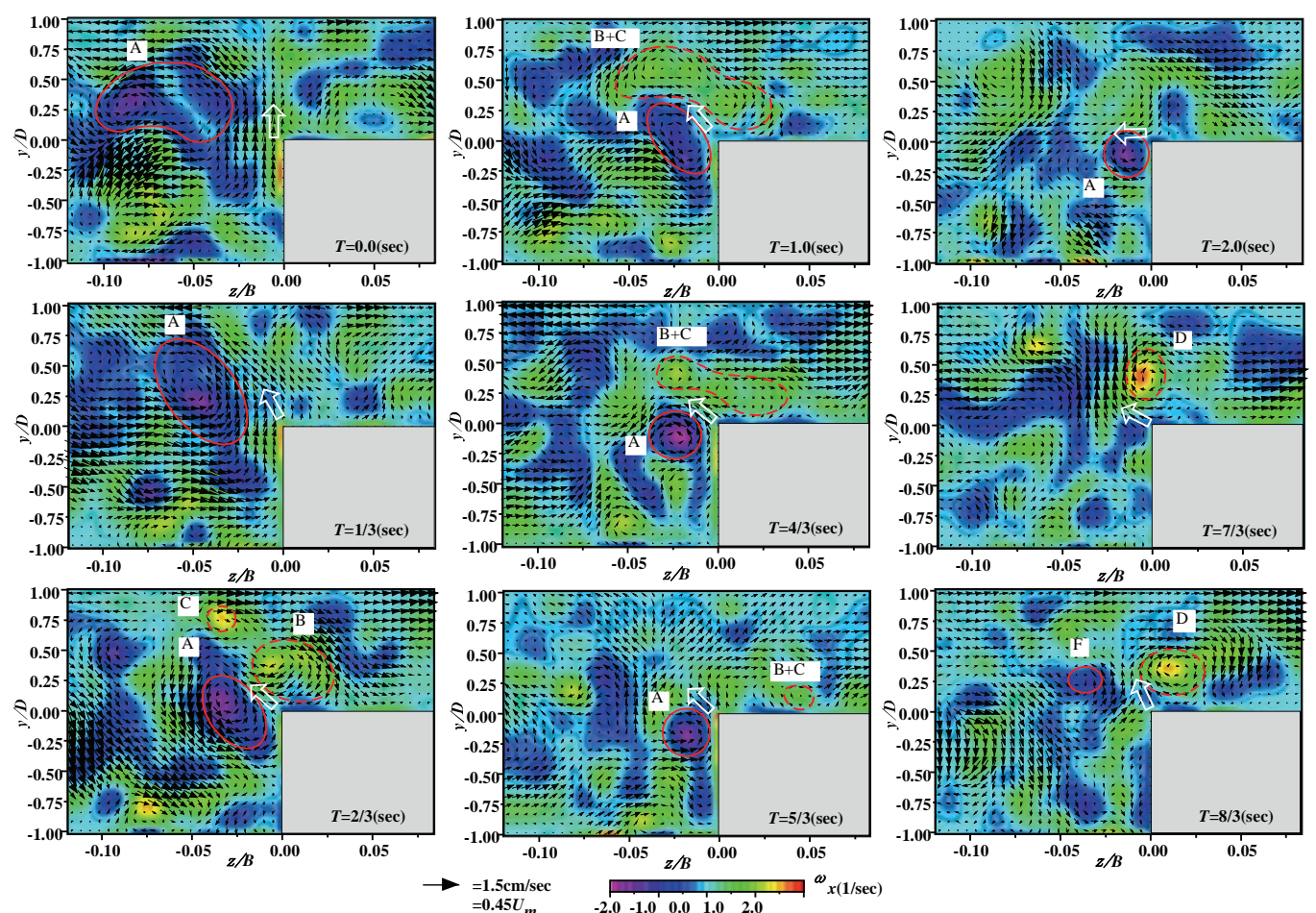

図-5 高水敷先端部周辺の瞬時二次流れ，瞬時渦度 $\left(\omega_{x}\right)$ 分布の経時変化(Case C)

矢印で示している。この矩印の向きは単独あるいは対を 成す旋回流の上昇部の方向と一致していることが明らか である. 3 つめ特徴は，瞬時二次流れの大きさは，図 -4(b)に示した長時間平均のそれに比べて著しく大きいこ とである. 例えば，高水敷先端部の白抜き矢印内の二次 流は断面平均流速 $\left(U_{m}\right)$ の $15 \%$ ，旋回流 A 内の最大值は $23 \%$ ，旋回流 A の底壁側に生成された上昇域では，最 大 $31 \%$ の值が認められる. 石垣, 今本 ${ }^{10)}$, 佐藤ら ${ }^{12)}$ も これと同程度の瞬時二次流れが生成されることを報告し ている.

これらの特徵を踏まえると，長時間平均の二次流分布 は，時針方向の瞬時の旋回流が高水敷に，反時針方向の それが低水路側にそれぞれ時空間的に集中することによ って生成されると考えられる。

\section{（3）高水敷先端部周辺の組織構造の時空間特性}

\section{a）組織構造の断面形象特性}

図-6には，各条件における流れ場の断面視の一例を 示している。(a)は高水敷高さよりも水深が小さい $H=3.7 \mathrm{~cm}(H / D=0.925)$ における横断面視である.この流れ 場では，水表面隅角部に縦渦構造(VS37)が長時間に亘 って形成されていることが観察された．佐賀らは，この 縦渦構造が開水路の水表面隅角付近の二次流の形成に重 要な役割を果たしていることを明らかにしている ${ }^{20)}$. (b) は $H=6.0 \mathrm{~cm}(H / D=1.5)$ の横断面視を示している. この条件 においては，高水敷上に形成された複数の縦渦構造 （VS60-1, VS60-2, VS60-3)が，顕著な横流れによって，側
壁方向へ移動する場合と低水路方向一張り出す場合があ ることが観察された。 (c)は $H=8 \mathrm{~cm}(H / D=2.0)$ の条件にお ける横断面視である. 本条件においても高水敷上に複数 の縦渦構造が形成されることが観察された．とくに，高 水敷先端部には, (c-1) の VS80A のような, 複数の渦構 造を内包し，水表面まで発達する大規模な縦渦構造が安 定して形成されることが観察された。このような縦渦構 造の低水路側では反時針の回転運動，高水敷側では時針 方向の回転運動がそれぞれ顕著であることが観察された. また，この構造は(c-2)の VS80B，(c-3)の VS80C のように， 低水路方向あるいは右岸側壁方向一傾斜運動をするが, 長時間の観察により，低水路方向への傾斜運動が顕著で あると認められた。.さらには, (c-1), (c-2), (c-3)内の赤 破線で示すように，高水敷先端部の縦渦構造の側壁側に は，比較的小規模な縦渦構造が安定して形成されている ことが認められた. (d)に示した $H=12 \mathrm{~cm}(H / D=3.0)$ の条件 では，高水敷先端部に形成された縦渦構造(VS120)は, $H=8 \mathrm{~cm}$ のそれと比較して右岸側壁方向への傾斜運動が 顕著になることが観察された。同図(e)，(f) はそれぞれ， $H=8 \mathrm{~cm}$ および $12 \mathrm{~cm}$ における高水敷先端部 ( $z=0.0 \mathrm{~cm})$ での縦断面視の一例である，高水敷先端部では，水表面 まで発達した縦渦構造(SVS80, SVS120)が，流れ方向に 連なって流下する様子が観察された。

以上のように，流れの内部流況の観察から，H/D>1.5 の流れ場では，高水敷先端部に縦渦構造が集中して形成 され，それが左右方向一傾斜運動していることが認めら れた.これらの縦渦構造の時空間特性ならびに速度情報 


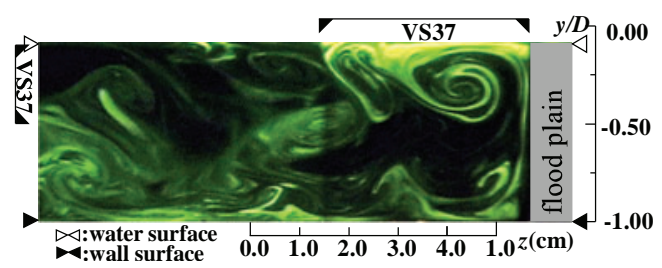

(a) $H=3.7 \mathrm{~cm}(H / D=0.925$, CaseF $)$

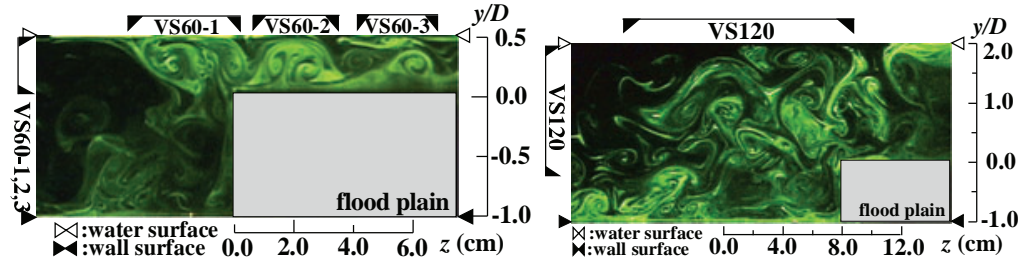

(b) $H=6.0 \mathrm{~cm}(H / D=1.5$, Case $D)$

(d) $H=12.0 \mathrm{~cm}(H / D=3.0$, Case $G)$

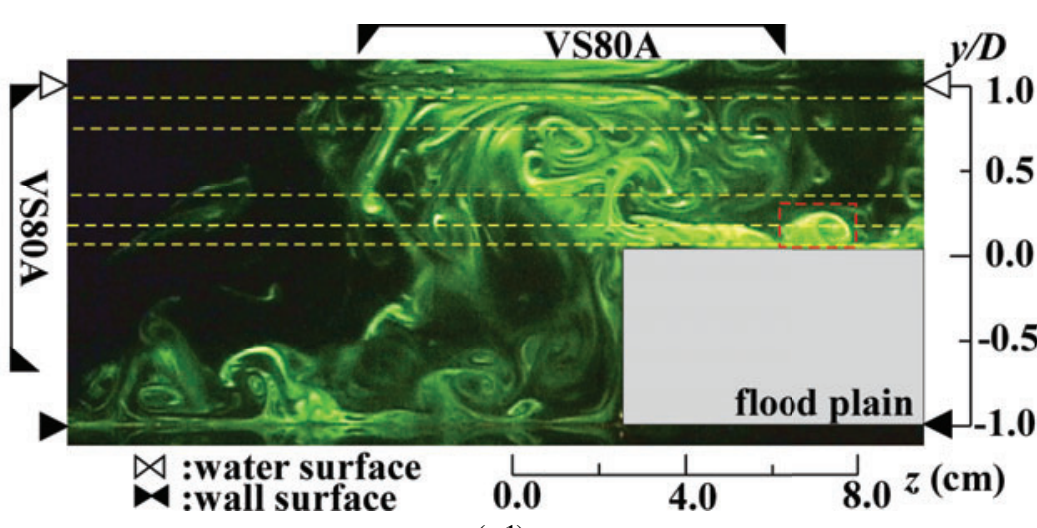

(c-1)

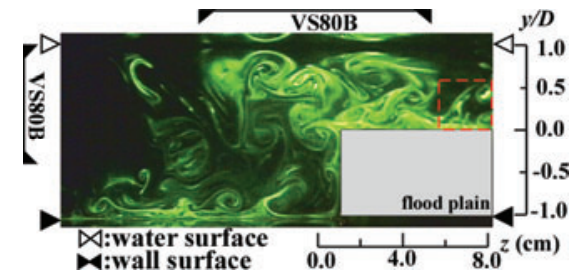

(c-2)

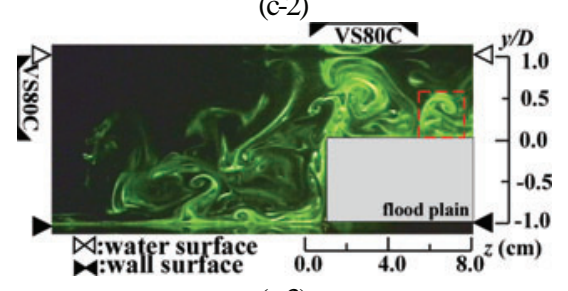

(c-3)

(c) $H=8.0 \mathrm{~cm}(H / D=2.0$, Case B)

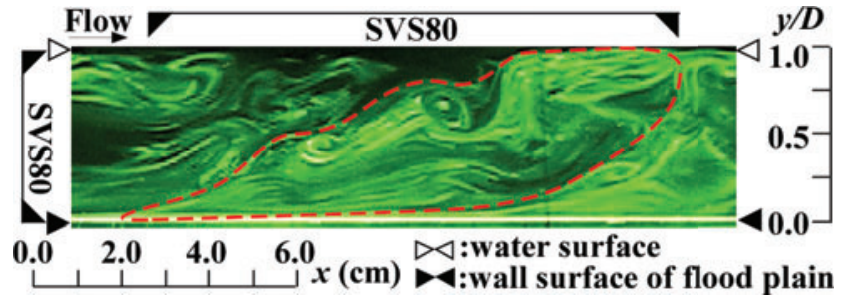

(e) $H=8.0 \mathrm{~cm}$ の縦断面視(Case B)

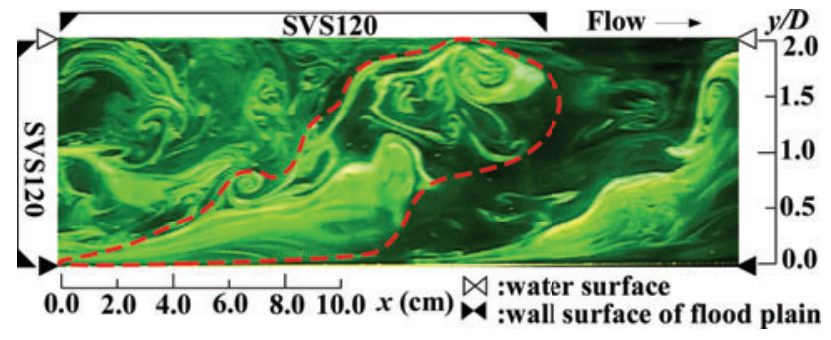

(f) $H=12 \mathrm{~cm}$ の縦断面視 (Case G)

図-6 組織構造の断面形象

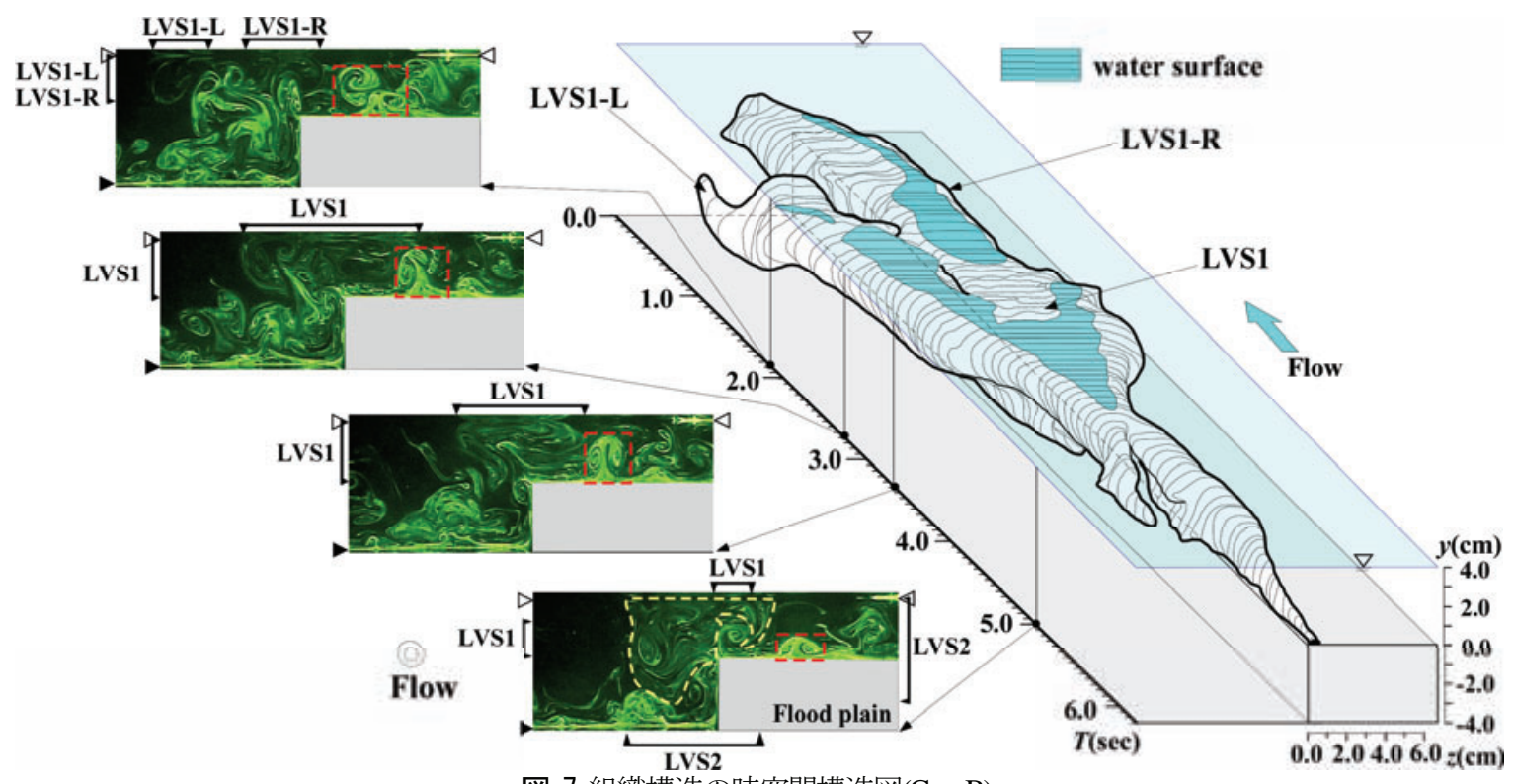

図-7 組織構造の時空間構造図(CaseB)

との相互関係については，高水敷先端部の二次流が発達 する典型的な条件と考えられる $H / D=2.0$ の流れ場を対 象に以下で詳細に検討する. b）縦渦構造の時空間構造

図-7は， $H=8 \mathrm{~cm} の$ 条件における高水敷先端部に形成さ れた縦渦構造の時空間構造困を示している. 本困は, 高 
(a) $y=0.25 \mathrm{~cm}$ $(y / D=0.0625)$

(b) $y=0.7 \mathrm{~cm}$ $(y / D=0.175)$

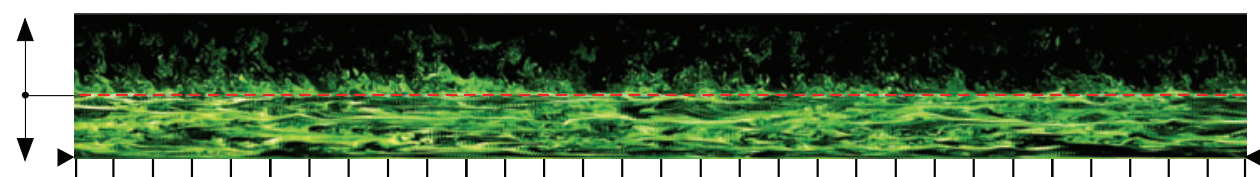

$\Delta$

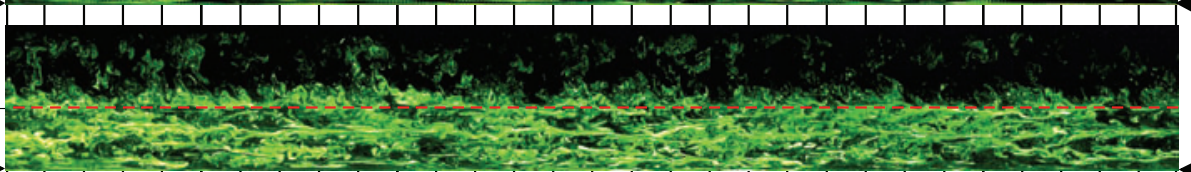

(c) $y=1.40 \mathrm{~cm}$ $(y / D=0.35)$

(d) $y=3.0 \mathrm{~cm}$ $(y / D=0.75)$

(e) $y=3.9 \mathrm{~cm}$ $(y / D=0.925)$

\section{$\Delta$}

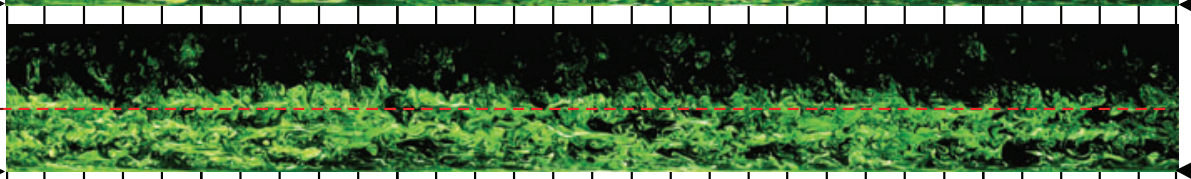

4
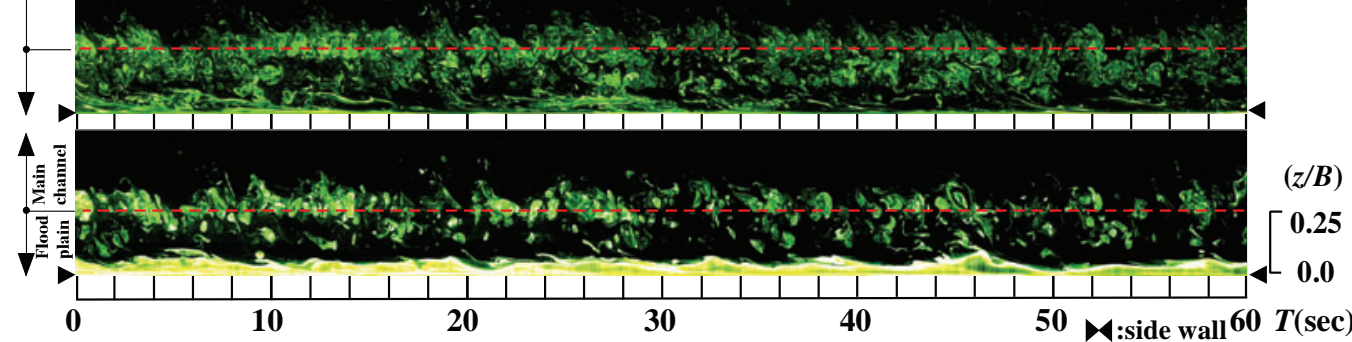

GSV2(T=11sec)

GSV3(T=6sec) GSV4(T=8sec)

(f) $z=0.0 \mathrm{~cm}$

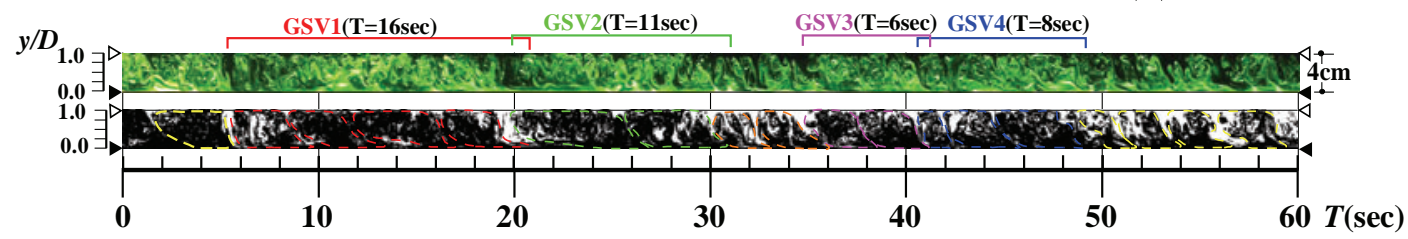

図-8 高水敷上に形成された縦洞構造の形成領域の経時変化 (CaseB)

水敷先端部付近における縦渦構造の横断面画像の輪郭を, 6.2秒間 (93枚)に亘って描き連ねて作成された. 上述のよ うに，高水敷先端部には縦渦構造が連なって流下寸るた め，上下流の縦渦構造が同一断面に可視化される．この ため，注目した縱渦構造の輪郭を決定する際には，ビデ オの連続画像を繰り返し観察した.

本図のLVS1は，高水敷先端部から水表面まで発達し た縦渦構造である. 本洞構造は, 反時針方向の回転が顕 著な縦渦構造LVS1-Lと時針方向の回転が顕著なLVS1-R が対を成して構成されており，全体的として低水路側に 張り出している. その横方向スケールは2.5 $H_{f p}$ 程度 $\left(H_{f p}\right.$ :高 水敷水深), 流れ方向スケールは, 描画時間とこの領域 での平均流速 $(U=2.6 \mathrm{~cm} / \mathrm{s})$ を乗ずると $4 H_{\text {巾 }}$ 程度となる. 図 -6(e)に示したように, 高水敷先端部には縦渦構造が流下 方向に連なって形成されており， $T=5.0 \mathrm{sec} の$ 横断面画像 に黄色破線で示したように，上流部の縦渦構造LVS-2が LVS-1の上流部に覆い被さるように形成されている。 ま た，本図中の横断面形象中の赤破線は，先述の高水敷先 端部の縦渦構造の側壁側に形成される比較的小規模な縦 渦構造の存在を示している.

\section{c）縦渦構造の形成領域の経時変化}

高水敷上に形成された縦渦構造の形成領域の経時変化 を図-8に示した．本図は，高水敷付近の横断面視画像を， 高水敷上面からの各高さにおいて，実寸厚さ $1 \mathrm{~mm}$ 程度で 水平方向に切り抜き，それらの画像を1800枚(60秒間)合 成した画像である。この切り抜き位置は図-6(c-1) に黄 色破線で示している.

本図の緑色の領域は, 縦渦構造の形成領域に相当して いる. また, 赤色破線は高水敷先端部 $(z=0)$ の位置を示 している. これらの図より, 高水敷上に形成された縦渦 構造の形成領域に関する次の3つの特徴が指摘される.

その1つは, 高水敷上には縦洞構造が集中して形成され る領域が複数存在することである.この特徽は，(a)，(b) に示した高水敷壁面近くにおける切抜き合成画像に認め られる. (a)には複数のstreak状の形象が認められる.こ れは, 画像の切断位置が縦渦構造の壁面近傍の細くなつ ている部分であること, また, 縦渦構造が長時間に亘つ て形成されているためstreak状の形象となる，(b)の合成 画像では, 縦渦構造の形成領域が高水敷先端部, 高水敷 中央付近，側壁付近の3箇所に集中していることが明瞭 に認められる．高水敷中央部付近のそれは，上述の高水 敷先端部の縦渦構造の側壁側に形成される小規模な縦渦

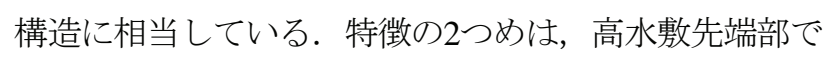
は, 水表面まで発達寸る大規模な縦渦構造が連続して形 成されるが，高水敷中央付近，側壁付近のそれは比較的 小規模であり, 高水敷上の縦渦構造の階層性が存在して いることである. この特徵は, (c)〜(e)の合成画像に見ら れるように, 切断位置が水表面一近づくに伴い, 高水敷 先端部の縦渦構造の形成領域は, 幅広く, 連続的である が，高水敷中央部のそれは間欠的となり，側壁付近のそ 


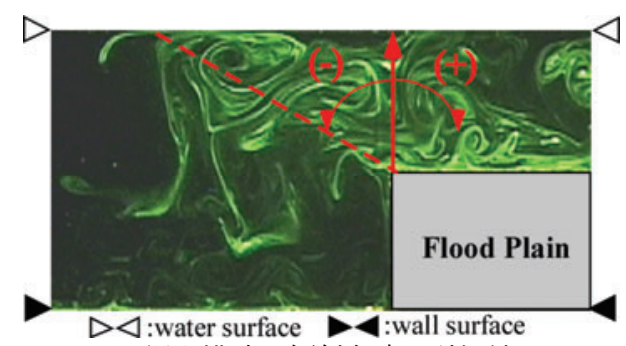

(a) 縦渦構造の傾斜角度の計測法

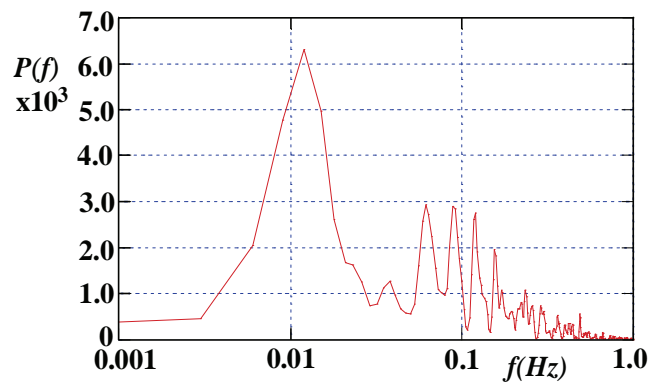

(c) 傾斜角度経時変化のパワースペクトル分布

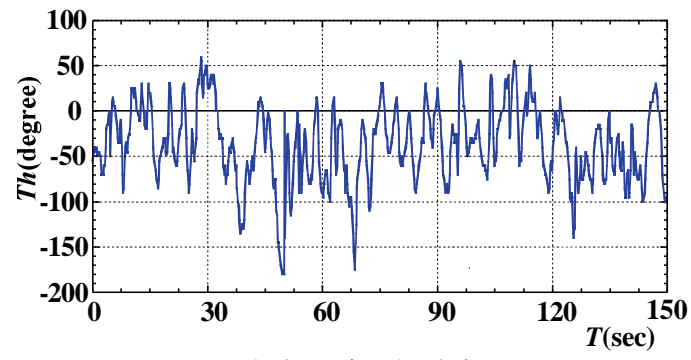

(b) 傾斜角度の経時変化

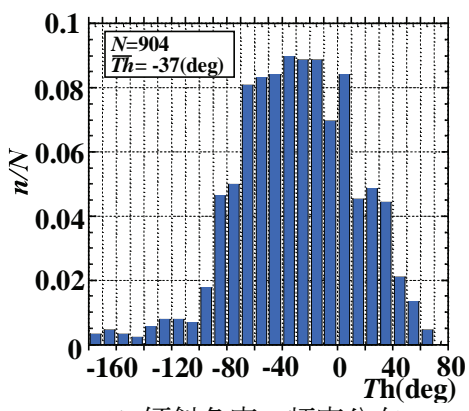

(d) 傾斜角度の頻度分布

図-9 高水敷上に形成された縦渦構造の傾斜角度特性（CaseB）

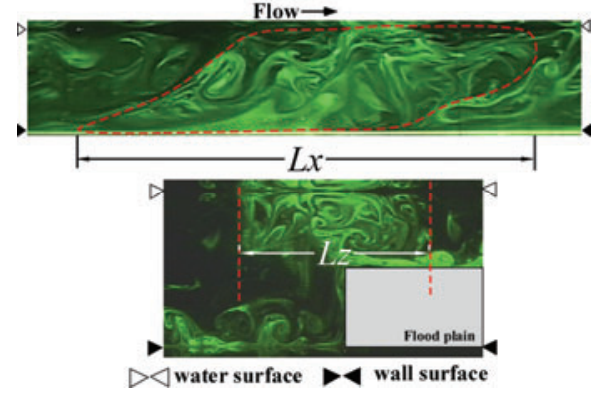

(a) 縦渦構造スケ一ルの計測法 $\left(L_{x} L_{z}\right)$

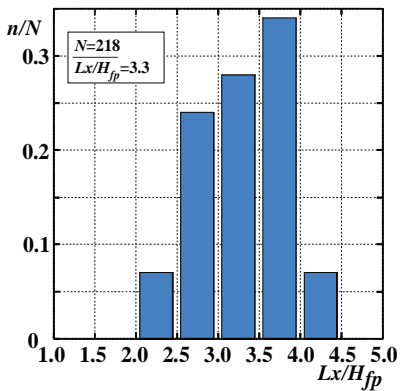

(b) 流れ方向スケール $L_{x}$

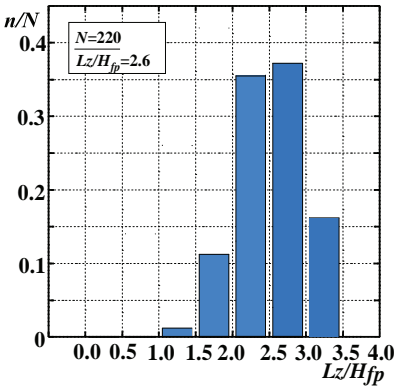

(c) 横方向スケール $L_{z}$

図-10 高水敷上に形成された縦渦構造の傾斜角度特性およびスケール特性（CaseB）

れは(d)においてほとんど消失していることに表れてい る. 水表面付近の(e)の合成画像では, 縦渦構造の形成領 域は高水敷先端部および側壁上に認められるが，側壁上 に形成された細い帯状の領域は，水表面隅角に形成され た縦渦構造の形成領域に相当している．特徵の3つめは, 高水敷先端部に形成された縦渦構造は, 連続かつ集団化 して流下寸ることである.この特徴は同図(f)から推察さ れる. 本図は，(a) (e)と同様の方法で, 横断面視画像を 高水敷先端部 $(z=0)$ において, 鉛直方向に切り抜いた画 像を60秒間(1800枚)合成した画像である。また，下図は その二值化画像である. 本合成画像からは，図-6(e)の高 水敷先端部の縦断面視で見られたように，水表面まで到 達する縦渦構造が連なって流下していることが認められ る. 二值化画像では縦渦構造の輪郭を破線で囲んで示し ている.これらを見ると縦渦構造の時間スケールは3秒 〜 7秒程度であり，この領域の平均流速 $(2.6 \mathrm{~cm} / \mathrm{s})$ を乗ず ると2 4.5 $h_{p}$ の流れ方向スケールを有寸る縦渦構造の流 下が推測される．また，色分けをして示したGSV1〜 GSV4のように, 複数の縦渦構造が集団となって流下し ていると考えられる. これらの集団は2４個の縦渦構
造から構成されており，その時間スケールは図中に示し たように6sec〜16secとなる。

\section{d）縱渦構造の傾斜角度およびスケール特性}

高水敷先端部に形成された縦渦構造の傾斜角度の計測 結果を図-9に示す。傾斜角度 (Th) は(a)のように, 縦洞構 造の断面形象の先端部と高水敷先端部とを結んだ線と垂 直軸との成す角とし，右岸側壁方向一の傾斜角度を正と した。(b)はこの角度を目視によって，1/6秒毎150秒間に 亘って計測した結果である. 傾斜角の計測值の大半は, 負の值を示しているが，これは，高水敷先端部の縦洞構 造の横断面視の観察結果と一致している. 計測值の波形 に注目すると，80～90sec程度の長周期の波形に，5〜 15sec程度の比較的短い周期の波形が重畳されている. 長周期の波形については計測時間が150秒であることを 考慮すると，有意性は乏しい，その有意性を見出すには， さらに長い計測時間が必要であり, 今後の課題としたい. (c)はFFT法による傾斜角度波形のパワースペクトル分布 を示している．本図より，0.01Hz付近におけるピークお よび $0.1 \mathrm{~Hz}$ 周辺に複数のピークが認められる. $0.01 \mathrm{~Hz}$ 付近 のピークは83秒の周期に相当し, 上述の長周期の波形に 


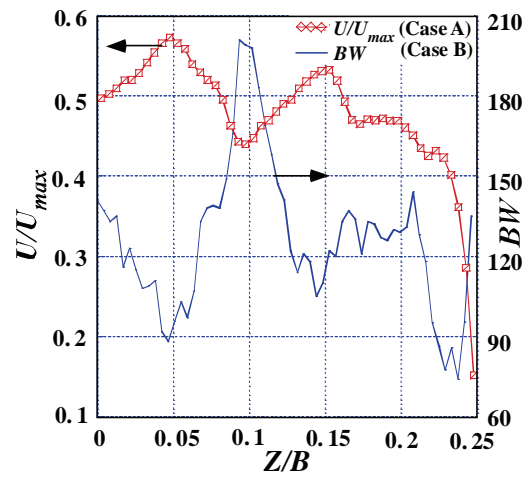

(a) $y=0.7 \mathrm{~cm}(y / \mathrm{D}=0.175)$

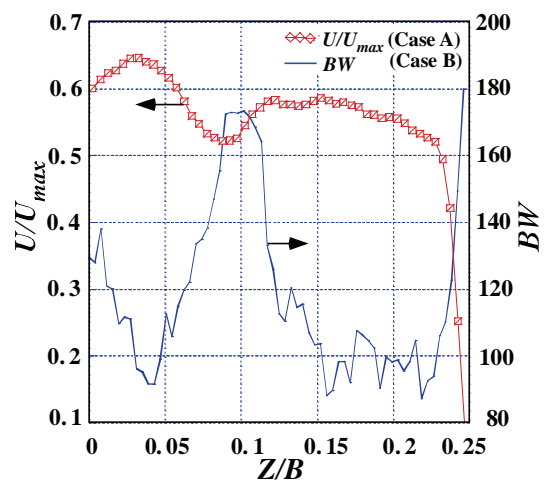

(b) $y=1.4 \mathrm{~cm}(y / D=0.35)$

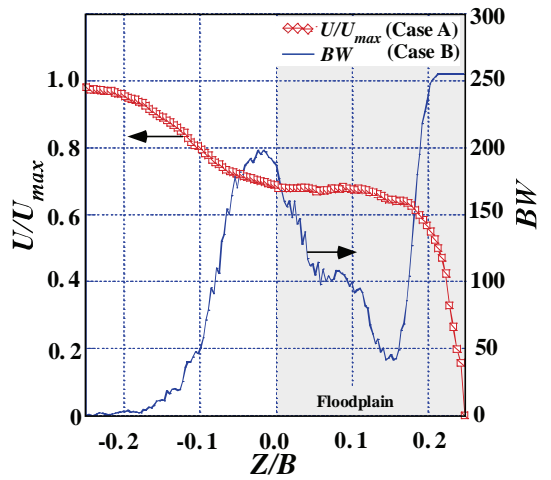

(c) $y=3.8 \mathrm{~cm}(y / D=0.95)$

図-11 高水敷上に形成された縦渦構造の形成領域と平均主流速分布との相互関係

対応している. 残りの4つのピークの周波数 (周期sec) は $0.062 \mathrm{~Hz}(16.1 \mathrm{sec}) ， 0.088 \mathrm{~Hz}(11.4 \mathrm{sec}) ， 0.12 \mathrm{~Hz}(8.3 \mathrm{sec})$ ， $0.16 \mathrm{~Hz}$ (6.3sec)であり，これらは図-8(f)に示した集団化し て流下する縦渦構造群(GSV1～GSV4)の時間スケールに 相当しており，縦渦構造の単独および集団としての傾斜 運動が推察される。 (d)は傾斜角度の頻度分布を示して いる. 縦渦構造の平均傾斜角は-370であり，平均的には 低水路方向への傾斜が顕著であることが明らかである.

図-10には，高水敷先端部に形成された縦渦構造の空 間スケールの計測結果を示している. (a)に示すように, 流れ方向スケールは， $Z=0$ における縦断面視において水 表面まで発達した縦渦構造の流下方向長さ $\left(L_{x}\right)$ を目視に よって計測した。 また，横断方向スケールは，横断面視 において水表面に到達した縦渦構造の横幅 $\left(L_{7}\right)$ を同様に 目視によって計測した. 同図(b), (c)に示した各スケール の測定結果から， $L_{x}$ は最頻值が3.5 4.0 $H_{f p}$ で平均值が $3.3 H_{f p}, L_{z}$ は最頻值が $2.5 \sim 3.0 H_{f p}$ で平均值が $2.6 H_{f p}$ であるこ とが明らかとなった，著者らは，単断面直線開水路に形 成される大規模縦渦構造のスケールの計測を行い，その 横方向および流れ方向スケールはそれぞれ $1.3 H$, $3.5 H(H$ : 水深 $)$ となることを報告している ${ }^{19)}$. これと比 較すると, 高水敷先端部に形成された縦渦構造の横方向 スケールは2倍となっている.

\section{e）縱渦構造と流速分布との相互関係}

図-11は，縦渦構造の形成領域と図-4(d)に示した高水 敷上の平均主流速横断方向分布との相互関係を示してい る. 縦渦構造の形成領域は，図-8に示した形成領域図を 二值化し，それらの時間平均值 $(B W)$ として求めた。 こ の值の最低值は0, 最高值は255であり，その高い值は縦 渦構造が同一領域に集中して形成され，流下しているこ とに相当している. (a) はy=0.7cm $(y / D=0.175)$ におけるBW と同じ高さにおける平均主流速分布を示している. 前述

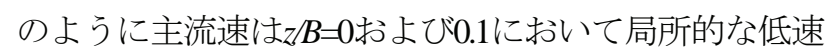
域が形成されている。，一方，BWは，z/B=0，0.1および0.2 で高い值を示し，その分布形状は主流速分布に対して明 瞭な逆位相を呈している.
比較的高い值は，上述した高水敷先端部の縦渦構造とそ の側壁側に形成される比較的小規模な縦渦構造の形成領 域に対応している. この小規模な縦渦構造の形成位置 $z B=0.1$ は，高水敷水深 $H_{p}$ の1.5倍となる. これは高水敷 先端部に形成された縦渦構造の平均横幅スケールの半值 よりやや大きい值であることから，この小規模縦渦構造 は高水敷先端部の大規模な縦渦構造の形成領域の極近く に形成されていると見なせる. (b) $の y=1.4 \mathrm{~cm} \quad(y / D=0.35)$ においても，(a)と同様にBWと主流速分布は逆位相とな り， $z / B=0,0.1$ における低速域と $B W \sigma$ 高い值を示す位置 が対応している. (c)は水表面付近の $y=3.8 \mathrm{~cm}(y / D=0.95) の$ $B W$ と主流速分布を示している. 高水敷先端部付近の主 流速の低減部分は(a), (b)と同様にBWが相対的に高い領 域に対応し, 両分布はほぼ逆位相を呈している.このよ うな縦渦構造の集中領域が相対的に低速となる特徵は, 縦栈粗度を有する開水路乱流においても認められており， 瞬時主流速についても, 縦渦構造の形成領域では相対的 に低速となることが報告されている゙77.

図-12 には，高水敷先端部に形成された縦渦構造の横 断面 DPTVの解析結果を示している. (a)の上困は縦渦構 造の横断面形象を示している. 図中の黄色の点は混入し た微細粒子である。下図には，この微細粒子の移動軌跡 から求められた瞬時の二次流ベクトル $(v, w)$ と縦渦構造 の横断面形象との重合困を示している. DPTV の動画像 からは, 混入した粒子の挙動から, 縦渦構造の渦巻き形 象と粒子の挙動が対応していることが明瞭に認められた. (a-1) $T=0.0$ sec には, 高水敷先端部の streak に認められるよ うに，対岸方向へほぼ水平に傾斜した縦渦構造の横断面 形象が可視化されている. その横断面形象は時針方向の 渦巻き形象を呈しているが，瞬時二次流ベクトルとの重 合罒から，その形象内には旋回状の二次流ベクトルが分 布していることが明らかである. (a-2)T=4/3sec では，高 水敷先端部から低水路水表面方向に斜めに伸びた streak とその両側に時針方向，反時針方向の対を成す縦渦構造 の横断面形象が可視化されている. 瞬時二次流ベクトル との重合図から，低水路水表面方向に斜めに伸びた 

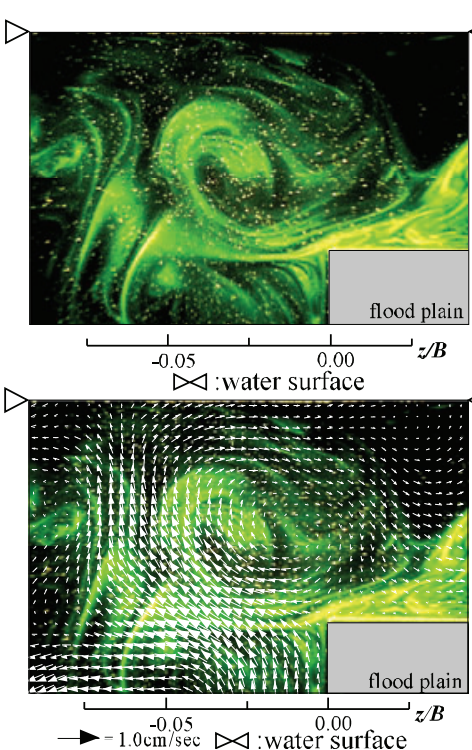

(a-1) $T=0$ sec
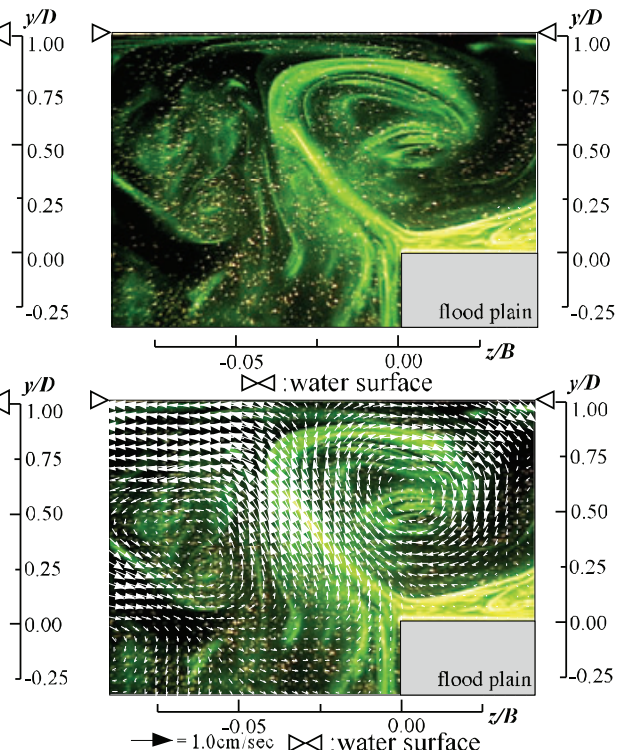

(a-2) $T=4 / 3$ sec

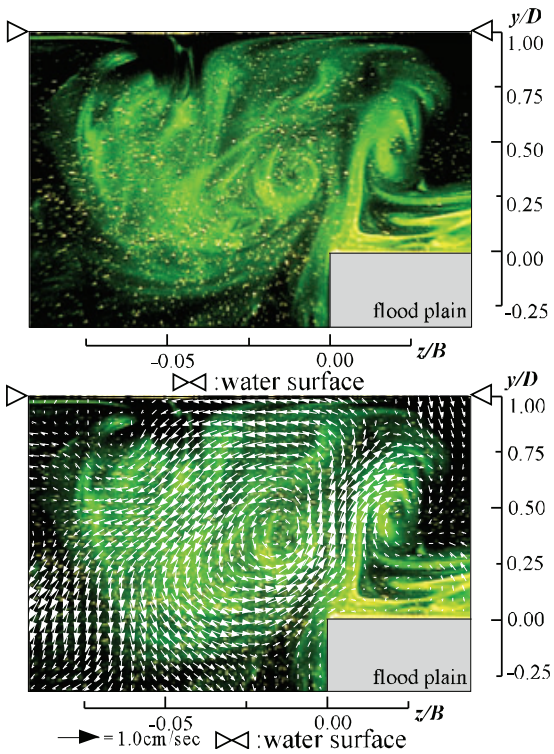

(a-3) $\mathrm{T}=11 / 3 \mathrm{sec}$

(a) 縦渦構造の横断面形象および瞬時二次流ベクトル分布 $(v, w)$ との重合図

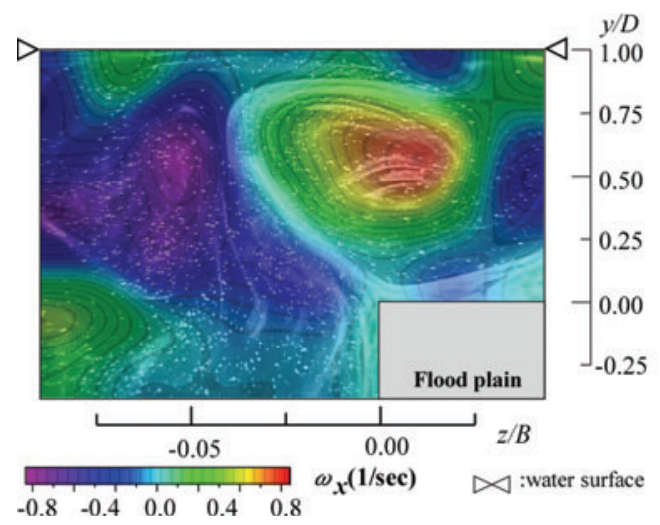

(b) $(\mathrm{a}-2)$ の瞬時渦度 $\left(\omega_{x}\right)$ 分布

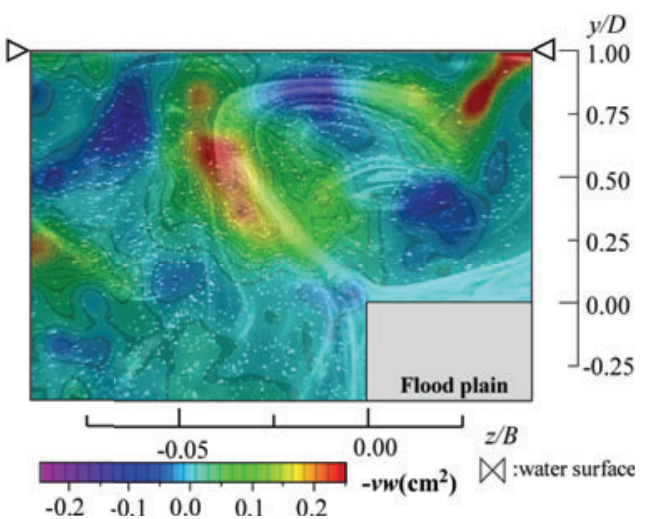

(c) (a-2)の瞬時レイノルズ応力(-vw)分布

図-12 高水敷先端部に形成された縦渦構造の横断面DPTV解析結果（CaseC）

streak 状の形象には，強い斜昇流の形成が認められ，そ の左右の渦巻き形象にはそれぞれ反時針，時針方向の旋 回状の二次流ベクトルが対応している. (a-3)T=11/3sec で は，高水敷先端部からほぼ垂直方向に形成された streak と，その左側には反時針方向の渦巻き形象を呈する大規 模な縦渦構造の横断面形象，その右側には小規模な時針 方向の渦巻き形象がそれぞれ認められる. これらの形象 には，(a-1)，(a-2)と同様に，左右それぞれの横断面形象 に対応する旋回状の二次流ベクトルが分布していること が明らかである，(b)には，(a-2)の二次流ベクトルから流 れ方向 $(x)$ を軸とする瞬時渦度 $\omega_{x}$ の等值線と横断面画像 を重ね合わせて示している，本図においては，正，負の 瞬時高渦度領域が, 縦渦構造の渦巻き形象に対応して分 布していることが明らかである. (c)には，同じく(a-2)の 二次流ベクトルから求めた瞬時レイノルズ応力 $(-v w)$ 分 布と横断面画像の重合図を示している. 正值および負值 の大きな值は，縦渦構造内およびその近傍に分布し，$v w$ の正值, 負值の領域が互いに向き合う点対称の分布 を呈している，-vw は渦度の生成因となることから 2)， この縦渦構造が，図-5 に示した高水敷先端部周辺の時 針・反時針方向の瞬時の旋回流ならびに斜昇流の生成因 であることが容易に推察される.

図-13 には，図-4(e)に示した，横断方向レイノルズ応 力 $(-\overline{u w})$ の等值分布において, その最大值が生ずる $y=1.0 \mathrm{~cm}(y / D=0.25)$ の位置に水平断面 DPTV を適用した結 果の一例である. 図中の赤色破線は高水敷先端部の位置 を示している. (a)においては, 高水敷先端部に形成され た縦渦構造の水平断面形象について, 上流側の構造を黄 色破線，下流側の構造を紫色破線でそれぞれ囲んで示し ている. それらの断面内には小規模な渦形象が認められ る. (b)は瞬時流速から同断面位置の平均流速分布 $(U(z)$, $W(\mathrm{z})$ )を差し引いて求められた変動流速ベクトル $(u, w)$ と 水平断面画像との重合図である. 本図より, 縦渦構造の 形成領域では相対的に低速であることが認められる。こ の変動流速から求められた瞬時レイノルズ応力 (-uw) 分 布を(c)に示している. 本図では負の高い值の分布が顕著 


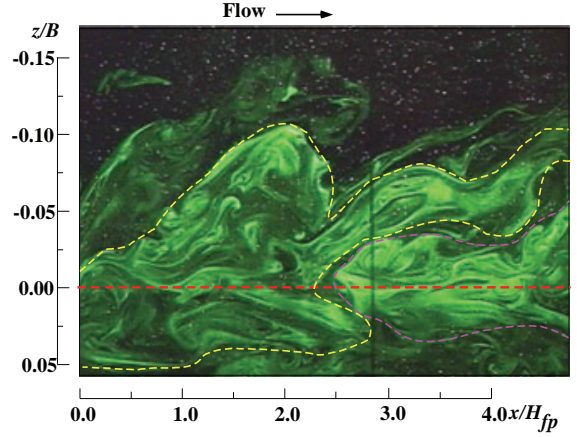

(a) $y=1 \mathrm{~cm}$ 水平断面DPTV瞬時画像

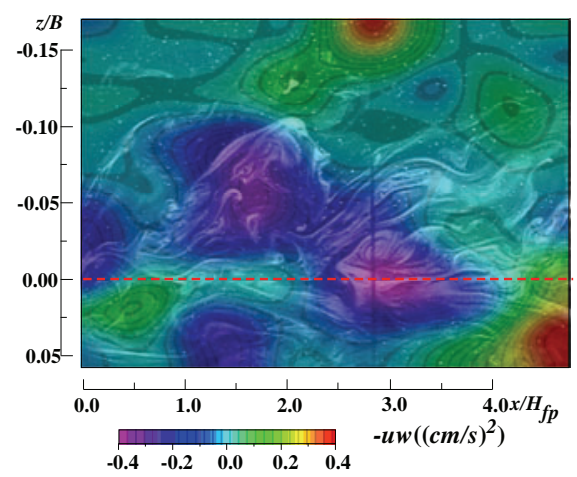

(c)横断方向瞬時レイノルズ応力(-uw)

図-13 高水敷先端部に形成された縦洞

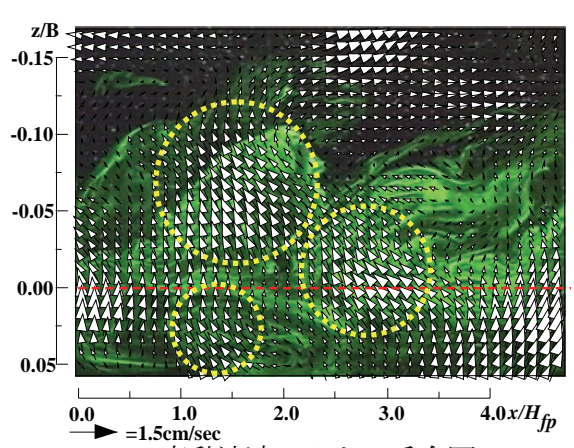

(b) 変動流速ベクトル重合図 $(u, w)$

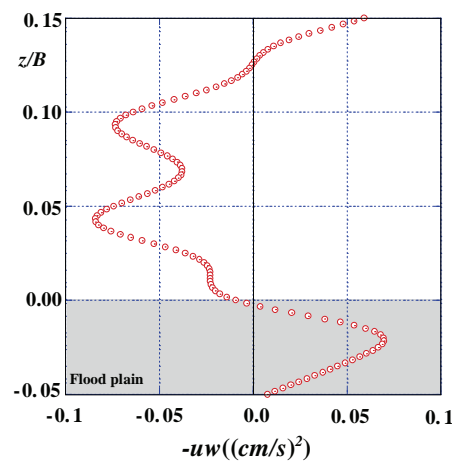

(d) 横断方向レイノルズ応力 $(-u w)$ 可視断面内の平均值 の水平断面DPTV解析結果(Case B, $y=1.0 \mathrm{~cm})$
であり，それは縦渦構造内に生じている4象限の変動流 速ベクトル $(u<0, w<0)$ の形成領域（黄色の破線内）に対 応している.このような変動流速ベクトル分布は, 高水 敷先端部の縦渦構造が高水敷壁面上の低速流体 $(u<0)$ を 低水路側水表面方向 $(w<0)$ 八輸送していることを示して いる. この瞬時レイノルズ応力分布を流れ方向に平均し たものが(d)である. 本分布においても，図-4(e)に示した 長時間平均分布と同様に高水敷先端部の低水路側には, 負の大きな值の分布が認められる.

以上のように，高水敷上に形成された縦渦構造の集中 領域は，局所的な低速領域と対応していることが明らか となった. また, DPTV を流れ場に適用することによっ て，高水敷先端部に形成された縦渦構造は，旋回状の瞬 時二次流れの生成および横断方向の瞬時レイノルズ応力 の生成に直接寄与していることが明らかとなった。

\section{4. 斜昇流の内部構造に関する概念図}

本研究において得られた知見を総合して，斜昇流の内 部構造に関する概念図を図-14に示した。高水敷先端部 付近には平均主流速による2つの速度せん断( $\partial U / \partial y$, $\partial U / \partial z)$ が生成されている。この2つの速度せん断の共存 によって，x軸周りの渦度 $\Omega_{x}$ の生成が促される ${ }^{23)}$. すな わち, 高水敷上面の速度せん断 $\partial U / \partial y$ にって $z$ 軸周りの 渦度 $\Omega_{\mathrm{z}}$ が生成され，それが低水路側壁上の速度せん断 $\partial U / \partial z$ の作用によって，渦軸が流れ方向に傾斜し時針方 向の渦度 $\Omega_{x}$ に変換される. 一方, 低水路側壁上では速度 せん断 $\partial U / \partial z$ にってy軸周りの渦度 $\Omega_{y}$ が生成され, それ が同様に高水敷面の速度せん断 $\partial U / \partial y の$ 作用によって反 時針方向の渦度 $\Omega_{x}$ に変換される. これらにより, 高水敷 先端部では，互いに回転方向の異なる対を成す流れ方向 渦度領域が生成されると考えられる.このような複断面 開水路流れの高水敷上には，縦渦構造の集中領域が複数 形成される. とくに，高水敷先端部には，水表面まで発 達する縦渦構造が安定して形成され, 流下に際しては集 団化する傾向が認められる，また，その側壁側には比較 的小規模な縦渦構造が安定して形成される. 高水敷先端 部の縦渦構造は, 左右方向に傾斜運動するが, $H / D=2.0$ の流れ場では低水路方向への傾斜が顕著となる. 同時に 本渦構造は，時針，反時針方向の旋回状の瞬時二次流れ を生成し，その集中領域は壁面付近の低速流体が上方 輸送されるために局所的な低速領域となる。また，本渦 構造は, 瞬時レイノルズ応力 (-uw)の生成にも直接寄与 している. このような高水敷先端部における縦渦構造の 存在は, Jong \& Choi ${ }^{16)}$ のDNSによる数值解析によって示 されている，彼らは，高水敷先端部には低水路渦 (main channel vortex) と高水敷渦(flood plain vortex)が対を成して 形成され，それらが高水敷先端部における二次流を生成 することを明らかにした，本研究で見出された高水敷先 端部の縦渦構造は, その諸特徵を考慮すると, Jong \& Choiが示した渦構造に相当すると考えられる. 


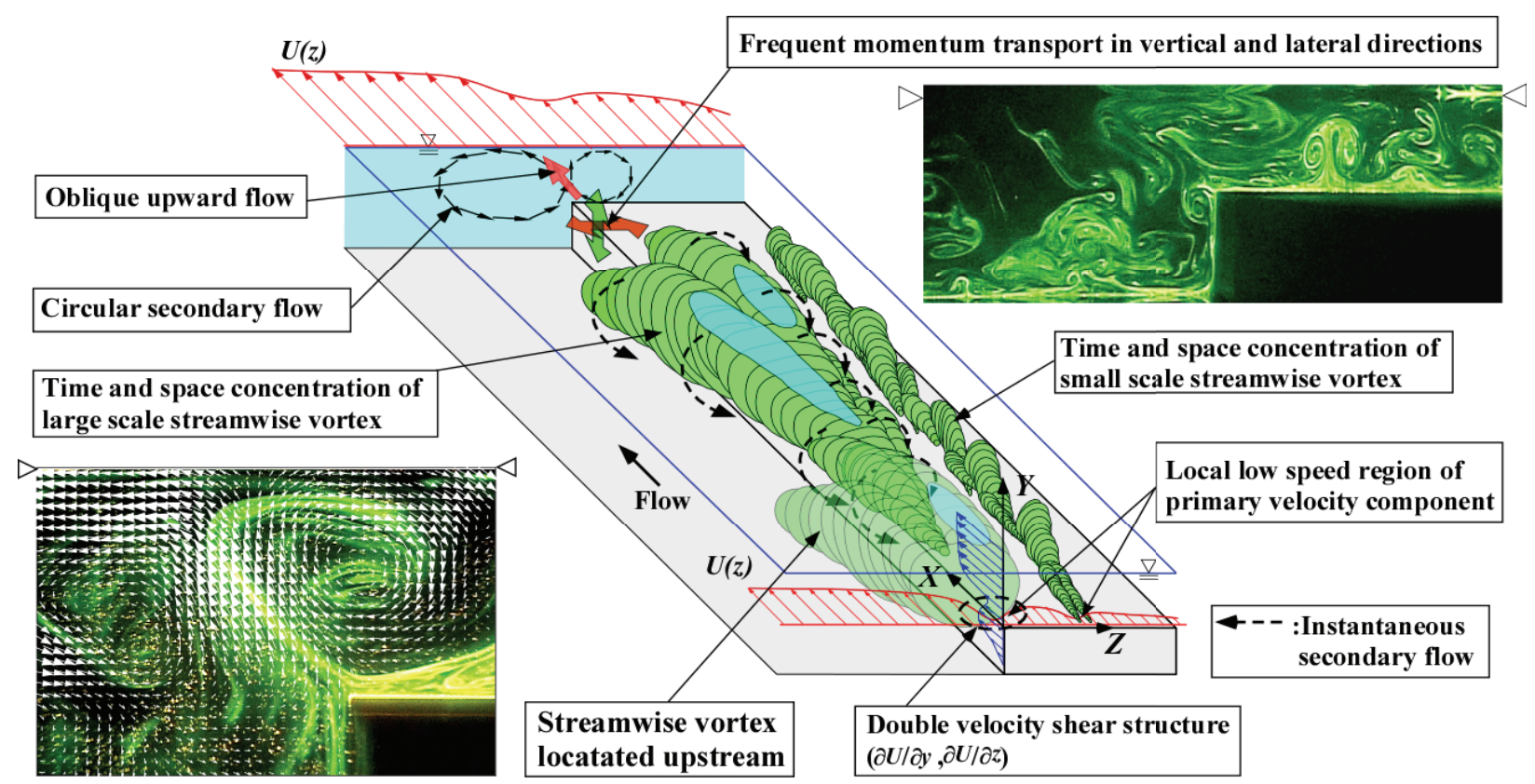

図-14 高水敷先端部周辺の二次流れと縦渦構造の相互関係に関寸る概念図

本研究で得られた結果を総合すると，高水敷先端部の 長時間平均特性である斜昇流を内包した対を成す旋回状 の大規模な二次流分布は，この縦渦構造の時空間的集中 によって生成されると結論付けられる.

\section{5. 結 論}

本研究では，低レイノルズ数の複断面開水路流れに形 成された斜昇流の内部構造の特徴を流速計測法，流れの 可視化を用いて検討した. 以下に，本研究において得ら れた結論を示す.

(1) 高水敷先端部周辺には，時針・反時針方向の瞬時の 旋回状の二次流れが，単独あるいは対の形態で集中して 形成され，斜昇流はその上昇部に相当していることが明 らかとなった。

(2) 高水敷上には，縦渦構造が集中して形成される領域 が複数存在し，とくに高水敷先端部には水表面まで到達 する縦渦構造が安定して形成される。 また，この構造の 側壁側にも比較的小規模な縦渦構造が安定して形成され る.

(3) 高水敷先端部に形成された縦渦構造は，左右方向へ の傾斜運動をするが，低水路水深 $(H)$ /高水敷高さ $(D)$ が 2の流れでは，低水路方向への傾斜運動が顕著となる.

また，その渦構造の横方向スケールは高水敷水深の 2.5 〜3倍, 流れ方向スケールは高水敷水深の3.5～4倍程度 を有している.

(4) 高水敷上における縦渦構造の集中領域は，局所的な 低速領域と対応する。また，高水敷先端部の縦渦構造は 斜昇流を内包した旋回状の瞬時二次流およひ瞬時レイノ
ルズ応力 $(-u w)$ の生成に直接寄与する.

(5) 上述のような特徵を有する縦渦構造の高水敷先端部 における時空間的集中によって, 長時間平均の特徵であ る斜昇流を内包した対を成す大規模な旋回状の二次流分 布が生成されることが明らかにされ，その内部構造に関 する概念困が示された。

謝辞 : 本研究は，平成19～21年度科学研究費補助金基盤 研究 (C)（課題番号：19560523, 「複断面開水路流れの 内部構造の解明と河岸防災手法の検討」）の援助を得て 行われた.ここに記して謝意を表します。

\section{参考文献}

1) Sellin, R. H. J.: A laboratory investigation into the interaction between the flow in the channel of a river and that over its flood plain, La Houille Blanche, No.7, pp.793801, 1964.

2) 池田駿介, 村山宣義, 空閑健 : 複断面開水路水平渦 の安定性とその 3 次元構造, 土木学会論文集, No.509/II-30, pp.131-142, 1995.

3) 福岡捷二, 藤田光一: 複断面河道の抵抗特性と河道 計画への応用, 土木学会論文集, 第 411 号/II-2, pp.63-72, 1989.

4) 池田駿介, 空閑健 : 直線複断面開水路流れに発生す る大規模水平渦列の安定性と運動量輸送に関する実 験的研究, 土木学会論文集, No.565/II-39, pp.73-83, 1997.

5) 今本博健, 久下俊夫 : 複断面流れの水理特性に関す る基礎的研究, 京都大学防災研究所年報, 第 17 号 B, pp.665-679, 1974. 
6) Tamai, N., Asaeda, T. and Ikeda, H.: Study on generation of periodical large surface eddies in a composite flow, Water Resource. Res., Vol.22, No.7, pp.1129-1138, 1986.

7) Tominaga, A. and Nezu, I.: Turbulent structure in compound open-channel flows, Journal of Hydraulic Engineering, ASCE, Vol.117, No.1, pp.21-41, 1991.

8) 禰津家久, 鬼束幸樹, 相良幸輝, 池谷和哉 : かぶり 水深の変化が複断面開水路流れの組織渦に及ぼす影 響に関する研究, 土木学会論文集, No.649/II-51, pp.1-15, 2000.

9) 禰津家久, 山上路生, 坂根由季子 : 水深変化する非 定常な複断面開水路流れの 3 次元乱流構造に関する 研究, 土木学会論文集, No.726/II-62, pp.61-71, 2003.

10) 石垣泰輔，今本博健：可視化法による複断面開水路 流れの 3 次元構造に関する研究, 土木学会論文集, No.515/II-31, pp.45-54, 1995.

11) Shiono, K. and Feng, T.: Turbulence measurement of dye concentration and effects of secondary flow on distribution in open channel flows, Journal of Hydraulic Engineering, ASCE, Vol.129, No.5, pp.373-384, 2003.

12) 佐藤弘行, 河原能久, 玉井信行 : Smagorinsky モデ ルによる複断面開水路乱流の解析，土木学会論文集， No.628/II-48, pp.115-130, 1999.

13) 杉山均, 秋山光庸, 松原珠 : 複断面開水路内の乱流 構造解析と縦渦生成に関する研究, 土木学会論文集, No.515/II-31, pp.55-65, 1995.

14）杉山均, 秋山光庸, 亀澤正之, 野口大介 : 傾斜側壁 を有する複断面開水路の乱流構造解析, 土木学会論 文集，No.565/II-39，pp.73-83， 1997.

15) Naot, D., Nezu, I. and Nakagawa, H.: Calculation of compound-open-channel flow, Journal of Hydraulic Engineering, Vol.119, No.12, pp.1418-1426, 2008.
16) Joung, J. and Choi, S.-U.: Investigation of twin vortices near the interface in turbulent compound open-channel flows using DNS data, Journal of Hydraulic Engineering, Vol.134, No.12, pp.1744-1766, 2008.

17) 渡辺勝利, 佐賀孝徳, 國弘栄司：底壁面に縦栈粗度を 設置した開水路乱流に形成された並列らせん流の内 部構造, 土木学会論文集 B, Vol. 62, No. 2, pp.186200, 2006

18）大成博文, 渡辺勝利, 佐賀孝徳, 斉藤隆, 波多野 慎 : 壁乱流の縦断面せん断構造, 土木学会論文集, No.593/II-43, pp.31-40, 1998.

19) Watanabe, K., Saga, T. and Kunihiro, E.: Large-scale coherent structure in turbulent open channel flow, $5^{\text {th }}$ International Symposium on Particle Image Velocimetry CD ROM Proceedings PIV'03, Paper No.3119, 2003.

20）佐賀孝徳, 大成博文, 渡辺勝利, 杉本博幸 : 開水路 乱流側壁領域の組織構造と二次流れの形成機構, 土 木学会論文集，No.677/II-55，pp.33-41，2001.

21）渡辺勝利, 森山拓士，佐賀孝徳 : 複断面開水路流れ の斜昇流と高水敷上に形成された組織構造の相互関 係，土木学会水工学論文集，第 51 巻, pp.649-654, 2007.

22) 大本照憲，林俊一郎：一般座標系高次精度 DNS の縦 筋河床流れへの適用，日本計算工学会論文集，Vol.3， Transaction of JSCES, Paper No.20020020, pp.171-179, 2001.

23) 河原源太, Javier Jimenez, Markus Uhilmann, Affredo Pinelli:壁乱流におけるストリークの不安定と流れ方 向渦度の生成メカニズム，日本機械学会論文集（B 編）， 66 巻 642 号, pp.383-391， 2000.

(2010.9.16 受付)

\title{
INNER STRUCTURE OF OBLIQUE UPWARD FLOW IN ONE-SIDED COMPOUND OPEN CHANNEL FLOW AT LOW REYNOLDS NUMBER
}

\author{
Katsutoshi WATANABE, Takuji MORIYAMA and Takanori SAGA
}

Characteristics of inner structure of oblique upward flow in one-sided compound open channel flows at low Reynolds number were investigated by using Particle Tracking Velocimetry (PTV) and flow visualization techniques. The results of flow visualization in the flows with relative deep flood plain depth show that some fixed formative regions of streamwise vortex exist and that large-scale streamwise vortices developing toward the water surface concentrate over the junction edge of the flood plain. The streamwise vortices have inclined motion toward the main channel and generate instantaneous secondary flow, local low speed regions and instantaneous Reynolds shear stress. On the basis of the results, time averaged properties, which is large-scale twin circular secondary currents including oblique upward flow, are caused by spatial-temporal concentration of streamwise vortices in the vicinity of the junction edge of the flood plain. 